\title{
Trends in Online Religious Processes during the Coronavirus Pandemic in Hungary-Digital Media Use and Generational Differences
}

\author{
Andok Mónika
}

check for updates

Citation: Mónika, Andok. 2021. Trends in Online Religious Processes during the Coronavirus Pandemic in Hungary-Digital Media Use and Generational Differences. Religions 12 : 808. https://doi.org/10.3390/ rel12100808

\section{Academic Editors:}

Anna Jupowicz-Ginalska,

Iwona Leonowicz-Bukała and Andrzej Adamski

Received: 29 July 2021

Accepted: 20 September 2021

Published: 26 September 2021

Publisher's Note: MDPI stays neutral with regard to jurisdictional claims in published maps and institutional affiliations.

Copyright: (C) 2021 by the author. Licensee MDPI, Basel, Switzerland. This article is an open access article distributed under the terms and conditions of the Creative Commons Attribution (CC BY) license (https:/ / creativecommons.org/licenses/by/ $4.0 /)$.
Department of Communication and Media Studies, Pázmány Péter Catholic University, 1088 Budapest, Hungary; andok.monika@btk.ppke.hu

\begin{abstract}
The present study shows how Hungarian churches and religious communities responded to the physical closure and relocation to online spaces in the spring of 2020, since while physical gates became closed, digital gates became opened. In the churches, work began in two directions with particular intensity. On the one hand, they organized their online appearance. On the other hand, they began to rethink their theological reflections on the possibilities of digital technology. The study also analyses both the event- and community-based presence of the churches as well as what they broadcast to their believers. The intention was to find the answer to what the presence of the camera meant in the process of live broadcasting, with a special focus on the visual elements and procedures that differed from the visual perception of real presence during streaming: the camera movement, the different viewing angles, the location of the cameras, the cut, and the sound quality. In other words, the believers had a new visual experience, an optical representation of reality, which afforded them a new type of interactivity and participation. In addition, the study highlights the generational differences that can be explored in digital transitions.
\end{abstract}

Keywords: COVID-19; digital religion; pandemic; streamed content

\section{Introduction}

The coronavirus pandemic of 2020 and its related closures, such as the introduction of social distancing both in Hungary and globally, have transformed people's everyday lives, affecting their work, education, shopping, entertainment, and their ability to keep in touch with family and friends. Hungarian data traffic providers were able to record an average $30 \%$ increase in turnover in the spring of 2020. The increase in social media use was even higher with 54\% in April. Physical and technological changes have, of course, also affected churches and religious communities. In April 2020, as a result of the coronavirus pandemic, a much more intense digital presence was observed in the daily lives of religions, churches, and their believers. In addition, Easter, the greatest religious celebration for Christians, as well as Passover for the Jews, were both in April. For the first time in the millennial history of both religions, their believers did not celebrate these events in offline communities but the rites of the churches appeared digitally.

In March 2020, at the beginning of the pandemic in Hungary, the channeling of public practices of faith to networks, intended for a temporary period, began. In the first wave of the digital transition, the same religious act, ceremony, or rite was transferred from the offline spaces to a digital online interface. During this period, the focus was on technology, the application of technology, or the lack or existence of digital user proficiency and media literacy. The aim of the churches and religious communities was to emphasize a visually similar experience as much as possible. The problems were also focused on this area, as well as technology transfer and the availability and accessibility of equipment. At this stage, there was still an inventory of losses, i.e., an overview of what religions and religious communities had lost during the digital switchover. In the second wave, 
attention was paid to the recognition of network media effects, and the moderation and opportunities discovered in the transformation came to the fore (Campbell 2020a). The aim of this research is to analyze the online presence of Hungarian religious communities in the 2020 period of the pandemic. The theoretical basis of the study is digital religious research (Campbell 2010, 2013; Hoover 2006). The empirical part of the research involves the analysis of online religious interfaces. The study draws on three sources: (1) from the database of Hungarian religious communities (Database of Hungarian Religious Communities, abbreviation MAVALLKA); (2) from the content of the "Christian Broadcasts Collection" Facebook page; and (3) from the page of the largest Hungarian online religious youth community, the 777 community. The aim of the research is to explore how Hungarian religious communities have used the opportunities provided by digital media in terms of maintaining the opportunity of leading a religious life.

\section{Summary of Research-Relevant Literature on Digital Religion}

From the second half of the 1990s, scholarly interest shifted to the relationship between the internet and religion (Campbell 2006, 2010, 2013; Cheong et al. 2012; Hoover 2006, 2012). A number of research groups have been set up in Europe and the United States. With the support of the European Union, the program called "Shaping of European Culture of Identity" ran from 2007 to 2013. It should also be mentioned that a multitude of scientific journals have been started focusing on the relationship between religion and the internet such as the Online-Heidelberg Journal of Religions on the Internet, Journal of Media and Religion, Religion and Society in Central and Eastern Europe, and Nordic Journal of Religion and Society, all of which feature authoritative studies on the subject.

The research on the subject has covered a wide range of areas, revealing religious interfaces and the content of digital network media and their impact on religious practices. Concerning a religious experience, it is important to highlight a characteristic media feature of the Internet which is that it is particularly suited to providing a sense of "immersion" in experiences. Over the past decade and a half, a number of analyses have examined the religious dimensions of video games, such as Second Life ((Connelly 2013) special issue of the Heidelberg Journal of Religion on the Internet). Researches have also appeared on the impact of virtual reality (virtual pilgrimage, MySalaam, MyCamino, applications Digital Rosary, Digital Mala Beads, confession applications), artificial intelligence (using chatbots), and live broadcasting, streamed religious events (Helland 2013; Hepp and Krönert 2010; Mann 2017; Fewkes 2019; Golan and Martini 2019). The emergence of social media in the early 2000s brought another change in the field, namely the merging of offline and online environments.

While in the 1990s Internet users managed their offline and online lives and actions separately, this changed in the world of social media where the two environments were intertwined. Researching online rites is embedded in the scientific background of this field, as the way people practice their religion and what their online rites look like is also changing in network communication. According to Kerstin Radde-Antweiler, the latter can best be called "patchwork rites". That is, they combine not one, but several religious traditions (Radde-Antweiler 2006). Two key concepts come to the fore in the study of online religious interactions, religious practices and rites: authenticity and authority. That is, what the media user considers authentic, and in whose hands the control of interfaces of network communication is. Media researchers have been working intensively on these issues since the early 2000s, focusing on research questions about whether or not religious practitioners consider online rites to be real; whether to participate physically in rites; whether only a religiously qualified person with offline authority can perform online rites, or can anyone do so; and how to transform offline rites into an online interface (Helland 2000, 2013; Andok 2017, 2018; Andok and Vígh 2017; Miczek 2008).

New media technology also has an impact on the expression and shaping of identity, particularly religious identity. As a result of secularization, religious faith, belonging to the church, and religious beliefs in Western societies extended to the private sphere. 
At the same time, in the secularized publicity of traditional mass media, the church as an institution appeared almost exclusively, and personal religiosity, religious identity appeared extremely rarely (and often only in thematic programs). Social media has, in fact, made (among many others) personal religious beliefs, religious commitment, and religious identity visible again (Ammerman 2003; Lövheim 2012; Elmasry et al. 2014; Chetty 2017; Neriya and Shahar 2017).

New technology is also affecting religious communities. Today, research on religious communities on the internet dates back some thirty years. Campbell and Vitullo (2016) divided this period into four major epochs, essentially in a chronological order. The first phase lasted from the late 1980s to the second half of the 1990s. It described and documented how each virtual group defines itself as a religious or spiritual group, independent of the institutional churches. The second phase can be characterized as a period of categorization, falling in the second half of the 1990s and the beginning of the 2000s. The common characteristics and different features of virtual religious communities were identified in the research. It was followed by a typology of the studied communities in terms of the presence or absence of the identified features. In the third period, the institutional churches that existed offline also began to take advantage of the potential of the Internet. Following Helland $(2000,2013)$, the researchers then distinguished two different phenomena, one being online religion, and by this term they refer to religious forms created on the internet. The other is religion online, which is the name given to the digital, religion-related communication of established institutional churches. In time, this also fell in the late 1990s and early 2000s. In the fourth, ongoing phase, they explore how offline and online religious practices and religious discourses intersect and interact with each other, or how believers integrate digital religious content and religious practices in their daily lives-that is, how the connection and integration of offline and online (religious) life, previously examined in strict isolation, takes place in everyday religious practices, in the digital space (Campbell 2013; Andok 2017).

In 2006, Henry Jenkins published his research on convergence culture. His book, Convergence Culture, became a much-quoted and much-criticized masterpiece of the first decade of the 2000s (Jenkins 2006). In his book, Jenkins does not analyse technological convergence, nor does he focus on how the mass communications, telecommunications, and data processing industries have merged. Rather, it examines the resulting social and cultural changes that can be seen in media user practice. From a methodological point of view, it captures the phenomenon of cultural convergence with the help of case studies. Ultimately, in convergence, Jenkins understands how media content flows across multiple media platforms, building on collaboration between professional media content producers and recipients, media users. After all, the active participation of consumers in the process is strongly necessary for the circulation of media content in social media. Analysing young people's media use habits, Boyd supplemented the theory of convergence culture with the idea of the networked publics (Boyd 2014). "Unlike me and the other early adopters who avoided our local community by hanging out in chatrooms and bulletin boards, most teenagers now go online to connect to the people in their community. ... She used Facebook to extend the pleasure she had in connecting with her classmates during the game.... Teens' mediated interactions sometimes complement or supplement their face-to-face encounter." (Boyd 2014, pp. 4-5)

In parallel, the American religion researcher Hoover raised the issue of the convergence of media and religion (Hoover 2006), which was further developed by Hjalvard: "The use of both mass media and social network media influences how religion is represented as well as how church and followers interact with one another. In order to reach audiences and users through the various media, religious organizations and individuals must be sensitive to the demands and conventions of using the media in question. Placing the media at the centre of a religious movement may involve reciprocal accommodation between media and religion to the extent that it makes no sense to distinguish between media and religious organization. This may be particularly true in North and South American contexts." 
(Hjalvard 2016, p. 10) While van Zoonen discusses the issue of convergence within the broader umbrella of mediatization: "MEDIATIZATION (or convergence): Religion has become a thoroughly mediatised experience." (van Zoonen). In the present research, we have analysed how the practice of religious and cultural convergence can be seen in the media use of believers.

In the year and a half since the outbreak of the coronavirus pandemic, researchers have become interested in the religious practices of churches and believers. The focus was on how the digital switchover was implemented by the churches during the months of closure. American research (Campbell 2020a, 2020b, 2020c) has also been supplemented with European analyzes (Przywara et al. 2021; Rončáková 2021; Tudor et al. 2021). The present study explains the Hungarian situation, highlighting the generational differences in the behavior of believers. The digital rites and ceremonies that took place in the online environment of the pre-pandemic times were mostly organized without the presence of a priest. That is, most of the digitized ceremonies were conducted by lay people. Of course, there have always been events in the church that did not necessarily require the direction of an official priest (e.g., worship in the Catholic Church). But while in the offline world there was little of this, on the digital interface most of the time one could encounter such a process. Among the digitally streamed rites, the Urbi et Orbi blessing of Pope Francis, presented on 27 March 2020, can be highlighted, where believers could not be physically present, but many hundreds of millions of eyes were nailed to the Holy Father through the media. American professor Heidi Campbell asked several church leaders to summarize their experiences of the pandemic (Campbell 2020a). Albert Bogle, head of the Church of Scotland, believed that in the months of the lockdown, more cooperation and co-thinking between the church and artists, musicians, and technologists became possible. In addition, church leadership has become more open to the digital world. Church leaders who had previously not thought very positively about the network were forced to rethink the significance and possibilities of the Internet. Thousands of church leaders began to stream, post, or use social media in other ways. Bogle sees all of this as forward-looking and useful thing since he believes the creativity of the Holy Spirit is endless and can even manifest itself in digital media use. At the same time, he also saw a good mission opportunity in the situation; people now spend more time online, as they can't go to cafes, clubs, and can also find religious content while surfing (Bogle 2020).

Arni Svanur Danielsson, a Lutheran church leader, says the online liturgy is more participatory, even if there is no Eucharist in it. It is a difficulty in streaming that the preacher knew his audience, his community, and the space where the liturgy took place in the offline situation, but he is uncertain about these on the internet (Danielsson 2020). Of the positives, pastor John Floberg who registered on Facebook at the time of the pandemic highlights that he was pleasantly surprised at how many "friend" marks he received, and how many people sent him e-mails regarding the religious content he posted. With that, he realized the fact that the social media itself was even strange for him, but full of acquaintances (Floberg 2020). In her study, Teresa Berger reviews the rites for the Catholic Church that may or may not appear online. Appearance is not conceived in terms of mediation, but in terms of real action. The researcher found that the rites associated with the main sacraments could not be digitized. The Catholic Church defines holiness as visible signs deriving from Christ that symbolize and convey the graces of salvation to believers. The number of sacraments in the Catholic Church is seven: baptism, confirmation, Eucharist, penance, anointing of the sick, marriage, and holy orders. None of these can be realized digitally, but it is important to note that most theological reflections were related to the issue of Eucharist (Berger 2020).

In the United States, a survey was conducted in March 2020 in which 1500 church leaders were asked about their reactions to the pandemic. The vast majority of respondents switched to digital broadcasting, 36\% had "only" a strategy for streaming, and 56\% tried to take into account the technological specificities of the internet. It is also worth taking a look at the data on what religious leaders found to be the biggest hindrances. 
For $51 \%$, it is about being able to create supportive interactions;

For $41 \%$, technology was the problem;

$28 \%$ say preaching, singing in an empty hall, in front of empty rows of benches;

For $25 \%$, it was the quality of the streamed music;

$23 \%$ say gathering people for online streaming;

$15 \%$ said something other;

$10 \%$ said program planning;

$7 \%$ accept criticism from people, religious leaders who disagree with streaming the ceremonies (MacDonald et al. 2020).

Swedish Lutheran religious leader David Silverkors highlights some important testimonies of the digital transition. According to the first, churches need a digital presence. The second is to know the digital reality of spiritual communities, but also to be aware of the values of traditional religious practices. The third is the need for the theological clarification on the appearance of churches in an online contexts (Silverkors 2020). The present study explains the Hungarian situation, highlighting the generational differences in the behaviour of believers.

\section{Research Questions and Methods}

With the digital switchover after the closure of the churches, it was possible to join religious and community ceremonies online and access religious content online, thus fundamentally changing many elements of religious communication (Carey 2009; Korpics 2014). Media and communication theories focus on and examine: (1) the contents of communication, i.e., the media message; (2) the creators of the contents; (3) the recipients; and (4) the context of the communication process. The present research also focuses on these areas when analyzing the media use of Hungarian churches and religious communities during the 2020 period of the pandemic. The study outlines what digitally streamed contents appeared in the media communication process. It presents the creators of religious media content and the theological and religious value considerations that determine the practice of content sharing. Finally, the study addresses the changed recipient context in the media communication process which refers to believers not consuming religious content or attending religious ceremonies in religious places (church, house of prayer), but joining the process of mediation in their own homes (mass, worship) or joining gatherings of religious communities.

The aim of the research is to present and analyze the changes in the elements of the communication process and, by doing so, it reveals what changes the digital transition caused by the coronavirus epidemic has brought to the life of Hungarian religious communities.

In terms of religious communities, the research relied on three sources, one for the MAVALLKA database, the other for the Facebook "Christian Broadcasts Collections" page, and the 777 community page. With the help of the MAVALLKA database, we have access to the data of communities that operate primarily offline, but may have a website or web 2 interface. The "Collection of Christian Mediums" also led us to communities that are not included in the MAVALLKA database since they are not linked to communities but to parishes. Finally, the 777 community, as the largest Hungarian, exclusively online community, was included in the study.

During the project the study of religious communities was carried out with the help of MAVALLKA. The mapping of religious communities in Hungary was completed in a comprehensive way in 2015 by the Department of Religious Studies of the University of Szeged, led by Professor András Máté-Tóth. The database of religious communities is freely available and researchable on the www.mavallka.hu (accessed on 27 March 2020) interface for social scientists, religious researchers and theologians. As it can be read on the introductory interface of the website: "The Database of Religious Communities in Hungary (MAVALLKA) is a social and professional online service that allows access to public data on religious communities in Hungary. The database contains basic institutional data of all 
religious communities operating in the country, such as its name, legal status, name of its official representative, primary site, sites per settlement (based on GIS), and links to its own websites." (www.mavallka.hu, accessed on 27 March 2020)

In our research, we examined what percentage of the 5234 religious communities in the database have an online appearance. In the case of online interfaces, we examined the presence of web 1.0 and web 2.0 separately, as well as whether there was a reference to the coronavirus among the digital posts and, if so, in what form (e.g., advertising a social occasion, broadcasting a ceremony, technical advice, reception guidelines). With the data obtained in this way, we can show what percentage of Hungarian religious communities is available (either to members of the community or to outside interested parties) on the internet and what types of content these communities share.

Separating web 1.0 and web 2.0 interfaces in research and data is important since one form provides different interactivity options for members of the community, respectively. The structure of web 1.0 websites is accessible to users individually (unrelated to each other) while followers of social network sites can also interact with each other; they are not just "consumers" of the information on the site.

The links to websites in the database included pages that required access, but these accounted for only two percent of communities with an online interface. That is, information related to the community was divided into two groups, some of which were accessible to all online visitors, while others were only available to members of the offline community. Communities from the following churches appeared in the database: Catholic, Reformed, Lutheran, Israelite, Greek Catholic, Church of the Faith, Adventist, Buddhist, Mormon, and Jehovah's Witness. The data were processed in October 2020 with five master students in communication at Pázmány Péter Catholic University. During data aggregation, the following results were obtained.

Hungary has a population of 9,937,628, of which 5,354,134 are religious (53.8\%). The number of religious communities is 5234 . The number of religious communities with web 1.0 interface is 1510. Proportion of communities with web 1.0 interface to total religious communities: $28.8 \%$. The number of religious communities with web 2.0 interface is 653 . Proportion of communities with web 2.0 interface compared to all religious communities: $12.4 \%$. Proportion of communities with a web 2.0 interface compared to a community with a web 1.0 interface: $43.2 \%$.

When collecting MAVALLKA's data, we came across websites that were no longer operational. During the coding, we considered them to be non-functioning pages, on the surface of which we did not find any entry newer than 2018, or the page was completely misleading (http:/ /www.segitoszuzmaria.hu, accessed on 1 April 2020). However, we didn't list pages where we could see "updating" or "maintenance." We found a total of 480 such sites, meaning that the proportion of "dead surfaces" accounted for 31.7 percent of communities with an internet presence. This is a fairly large number, which can be explained by the fact that five years have elapsed between the data collection and the current analysis, which is a long time in the online space. If only a community leader or a few members operated the sites, due to the lack of feedback and real interaction, they might have given up. Similar consequence could have been if a church person operating the digital interface had been relocated to another place of service and his successor was no longer ambitious for an online presence. All of these could have led to the "death" of one site at a time.

We also examined the proportion of communities that have not only web 1.0 but also web 2.0 appearance. We found 653 such communities, representing 43.2 percent of all listed digitally existing communities. The web 2.0 interfaces were mostly Facebook pages, we rarely came across a YouTube channel.

We also summarized whether there was a reference to the coronavirus pandemic on either the web 1.0 or web 2.0 interfaces, and we found that in 597 cases there was. This represents 58 percent of truly live digital surfaces. In addition, we found 264 links that did not point to a single website, but to a so-called collection page, such as catholic.com, 
reformatus.com or evangelical.com. This was 25.6 percent of the sites that worked, meaning every fourth. It can be seen, in the case of communities associated with traditional church institutions, that the digital interface will also reflect the centralization that is characteristic of that particular church.

In addition to the MAVALLKA database, we also analyzed the contents of the "Christian Broadcasts Collections" Facebook page. This Facebook page acted as an alert page and will continue to do so during the many waves of the pandemic. On this interface, the poster describes things such as which parish, when, what mediation will be available, where believers can join in, etc. (Available: https://www.facebook.com/groups/845140862575770, accessed on 28 March 2020) The information on the streaming concerned the Catholic, Reformed, Greek Catholic, and Methodist churches. Among them were broadcasts related to diocesan sites (Esztergom, Veszprém) and monks related to monastic orders. From the latter, we examined the content of the Benedictines, Franciscans, and Jesuits in terms of content. Data collection took place in March and April 2020, during which time 94 posts appeared on the page.

As a third source, interfaces of the 777 community were used for the research, as they represent the largest Hungarian online religious youth community (https:/ / www.facebo ok.com/777blog.hu, accessed on 16 March 2020). The 777 blogs were launched in April 2016 by Zoltán Martí and are co-written by 15 young bloggers. The community's Facebook page has 76,000 followers, and they have an Instagram page with 14,000 followers, and a YouTube channel with 6800 subscribers. Data collection took place in March and April 2020, during which time 54 posts appeared on the site.

In the course of content research, we thought in the framework of religious media convergence based on the theory of cultural convergence (Hoover 2006), analyzed the content and revealed usage patterns that were made possible by the presence on the digital interface.

\section{Digitally Streamed Contents}

In an emergency declared due to the pandemic, believers were not allowed to visit churches, houses of worship, or other religious community spaces. Digital network media became the place of the religious practices. New ways of religious experiences and practices have emerged in the digital environment. However, it has also required media users to make these practices public (Sbardelotto 2016). In this chapter, we look at what types of content were delivered by different churches and religious groups and what online community meeting opportunities were provided for their followers. It is worth distinguishing between event-based and community-based streaming, the former including masses, prayer classes, sacramental worship, etc., while the latter covering non-liturgical group discussions of believers. Of course, it is not possible to make a sharp distinction between the two, but rather to say that in one type is the event, in the other the community is more emphasized. There is no doubt that an important element of belonging to a religious community is the common liturgy. However, building a digital community requires not creating only a technological but also user environment, otherwise communities will be much more diffuse than their offline counterparts.

Among the event-based broadcasts, we need to highlight masses. Many Catholic parishes streamed Sunday mass with their own techniques, but some of them shared only the preaching. The platform of the broadcast was mostly the stream function of Facebook, and if the parish or diocese had not only a Facebook page, but also a You Tube channel, the recorded content was uploaded there as well. The starting points for my collection was the Facebook page called "Christian Broadcasts Collection," which has acted as an attention diverting site and will continue to do so during the second and third wave of the pandemic. On this site the post writer informs the others about the available streaming. It was extremely important to identify the pattern that video viewers were in all cases more than the probable number of those visiting the mass physically. To give just a few interesting facts: the Easter Mass of St. Stephen's Basilica was watched by more than 10,000 people, 
and more than 11,000 people celebrated the mass with Cardinal Peter Erdö. The Benedictine Easter ceremony in Pannonhalma was followed by almost 5000 people, about the same number from the Great Reformed Church in Debrecen. The smaller parishes also had hundreds of viewers. However, the most popular was arguably the Csíksomlyó Pentecost broadcast, which was watched by 65,000 people. The Catholic Church and parishes also shared additional liturgical occasions (sacramental worship, vesper, prayer, rorate), but ecclesiastical-cultural contents were also uploaded, such as book recommendations, daily thoughts, or even theological discussions. The Easter conference of the Franciscan Order was watched by five to nine thousand people. The Reformed Church shared worship services, as well as a video containing technical assistance. The Lutheran Church streamed worship. The Jewish community didn't broadcast religious ceremonies, but rather content related to educational activities such as Virtual Beth Midrás. ${ }^{1}$

The present research also draws on the theory of cultural convergence and religious convergence. In our study, we dealt with the practice of religious and cultural convergence in the media use of believers. Our research questions related to the proportion of content created by official church organizations and content created by believers on the websites examined (MAVALLKA database) and on the FB pages (Christian Broadcasts Collections, 777 community) and what thematic field these contents can be classified into.

It was supposed if we would get a different result in terms of shared content, depending on whether it was an official church site (MAVALLKA data) or a group to which church people and lay people posted (Christian Broadcasts Collections) or young believers write the site (777 communities).

The following content types have been identified for encoding:

- Information about the pandemic situation, the operation of churches at the time of the pandemic;

- Information about the time of online religious ceremonies;

- Live broadcast of a religious event (mass, worship, cross) and sharing of the recorded broadcast;

- Sharing lectures related to religion (catechesis, spiritual practice, etc.);

- Sharing biblical quotes and creeds;

- Call for online (organized by believers) religious activity, joint online religious activity (prayer chain);

- Life guidance for religious life (relationships, conflict management);

- Other (technical information for broadcasts).

Analysing our three data sources, we obtained the following data based on the established content typology (examining 597 entries from MAVALLKA, 94 items from the Christian Broadcasts Collections, and 54 items from the 777 community). See Table 1.

Table 1. Distribution of content types.

\begin{tabular}{|c|c|c|c|}
\hline & MAVALLKA & $\begin{array}{l}\text { Christian Broadcasts } \\
\text { Collections }\end{array}$ & 777 Community \\
\hline $\begin{array}{l}\text { Information about the pandemic situation, the operation of } \\
\text { churches at the time of the pandemic }\end{array}$ & $76.4 \%$ & $3.2 \%$ & $1.9 \%$ \\
\hline Information about the time of online religious ceremonies & $13 \%$ & $57.4 \%$ & - \\
\hline $\begin{array}{l}\text { Live broadcast of a religious event (mass, worship, cross) } \\
\text { and sharing of the recorded broadcast }\end{array}$ & $6.1 \%$ & $34 \%$ & - \\
\hline $\begin{array}{l}\text { Sharing lectures related to religion (catechesis, spiritual } \\
\text { practice, etc.) }\end{array}$ & $2.3 \%$ & $4.2 \%$ & - \\
\hline Sharing biblical quotes and creeds & - & - & $37 \%$ \\
\hline $\begin{array}{l}\text { Call for online (organized by believers) religious activity, } \\
\text { joint online religious activity (prayer chain) }\end{array}$ & - & - & $11.1 \%$ \\
\hline $\begin{array}{c}\text { Life guidance for religious life (relationships, conflict } \\
\text { management) }\end{array}$ & - & - & $48.1 \%$ \\
\hline Other (technical information for broadcasts) & $2.2 \%$ & $1.2 \%$ & $1.9 \%$ \\
\hline
\end{tabular}


The sharing of official information was dominantly present on official interfaces (MAVALLKA), with three-quarters of the content being such an entry. Lay-operated online interfaces circulated less of this information (777 community). Broadcasts were encountered in a decisive way on the attention-gathering, collecting site (Christian Broadcasts Collections), while on the site run by young laymen (777 community), the most of Christian life guidance and creeds was found.

However, there were large differences in user responses to shared materials. On average, the published contents received the following reactions. See Table 2.

Table 2. Average of online reactions.

\begin{tabular}{cccc}
\hline & MAVALLKA & Christian Broadcasts Collections & 777 Community \\
\hline Giving a like & 6 & 22 & 1.200 \\
Comment & 2 & 2 & 105 \\
Sharing on own site & 1 & There is no sharing option on this site & 325 \\
\hline
\end{tabular}

Thus, it can be seen that content edited by lay people elicits much greater receptive activity from followers. Moreover, the members of the 777 community are religious according to the teaching of the church based on their own religious self-classification, so they are also closely related to the historical churches (Andok and Vigh 2017). The post that triggered the most activity was a call to a prayer chain on 14 March 2020. (Available at: https: / / www.facebook.com/777blog.hu/posts/1530744267083267, accessed on 18 March 2020).

After setting up the typology and performing an analysis, some pattern elements emerged from the broadcasts.

- In addition to the guidance of the church and the leadership of religious-monastic community, individual (priestly, monastic, lay) activity and ambition played a major role in the realization of streaming. (For example, streaming from the Szolnok Reformed Church on 29 March 2020. https: / / www.facebook.com/groups/8451408625 75770/ posts / 850526355370554, accessed on 29 March 2020);

- Offline data of religious communities and religious affiliation was reflected in the number of viewers of online broadcasts: viewership was higher for historical churches than for smaller ones. For example, the video of the Hungarian Methodist Church, which has 2400 members, will be less watched than those of historical churches, but not necessarily proportionately less (https:/ / www.youtube.com/watch?v=ejvrUwTZiMI, http:/ / www.ksh.hu/nepszamlalas/tablak_vallas, accessed on 20 April 2020);

- Those who opted for online streaming could always expect more viewers than the number of participants in the offline event. Tolnatáj Television streamed mass from a little village, Dunaszekcső, the video was viewed by 1800 people, while the number of real participants was 60-80 people. (https:/ / www.facebook.com/watch/?v=349804 032677408, accessed on 20 April 2020);

- Although religious ceremonies are particularly sensitive content, compared to the average commenting attitude, there were few trolls, and little mockery and irony on these sites. In many cases, the comment function was switched off. (https:/ / www.youtube. $\mathrm{com} /$ watch?app=desktop\&v=enTKsjuajFQ\&fbclid=IwAR3FoXykTjVnsdTfkskRRPFq XJrUGBkc4gqMCY3eY6C22gY9LqkUosZtN8Y, accessed on 20 April 2020);

- The regularity revealed by Albert-László Barabási also implies that those who arrived on the digital sphere earlier started collecting followers sooner, gained a considerable advantage, and that this advantage is maintained or even increased due to the pattern of the popularity connection (Barabási 2013);

- The network effect related to spatiality means independence from geographical space. After all, the internet has brought a new pattern in the interconnection of physical places. And this has been confirmed regarding the churches. When people attend a religious ceremony offline, be it a mass, a service, or a prayer hour, they usually go to a church or synagogue near where they live. Online broadcasts, on the other 
hand, will be chosen based on their personal attitudes, sympathy, or the credibility of the priest conducting the ceremony. It can already be seen that for a more popular Hungarian priest, pastor or rabbi, YouTube shows more than ten thousand views for a ceremony. This far exceeds the number that could have been physically present at the event, as their audience could come and join the network space geographically from anywhere. The worship of the Lutheran Church in Romania could be watched not only by Romanian Lutherans (https:/ / www.youtube.com/watch?V=Fpox6ICq5ws);

- The global impact could hardly be detected, with few following the streaming of the major ecclesiastical centers, with the exception of the Vatican. Rather, the attachment to the local community was reflected in the data and the influence of spiritual centers (Benedictine, Jesuit, Franciscan). In April 2020, EWTN was watched by 4400 people worldwide, while Benedictine broadcast from Pannonhalma, for example, was watched by more than 8000 people. (https: / / www.youtube.com/watch?v=QeOMZ5 O79fg\&list=PL98FC02E5AA17A7C8\&index=478, https: / /www.youtube.com / watc $\mathrm{h} ? \mathrm{v}=687 \mathrm{vFJ} 2 \mathrm{gt}$ 8\& list=PLHI88zWI08AI2xIXaI1LrAfkQsr, accessed on 20 April 2020)

- As a result of media convergence, broadcasts that are embedded in other interfaces will have a higher viewership. For example, if a broadcast is taken over by a religious radio (Hungarian Catholic Radio, Mária Radio) or television (Bonum TV, EWTN television) and shared on its own platform, it is also a factor that increases viewership. It was broadcast from St. Stephen's Basilica by Bonum Television on 10 April 2020. (https:/ / www.youtube.com/watch?v=RCpbu0K6uU0\&list=PLC7BrO_Z PZAA8knE5zrKIFlfAV8Of0A8_\&index=705, accessed on 10 April 2020).

Examining viewer data curves, it was found that in the weeks or two after the announcement of the emergency 2020, the proportion of religious broadcasts was highest. This can be traced back to two reasons, one is situation of uncertainty and fear as in such circumstances the proportion of people who turn to religion or spiritual content usually increases (Sinding Bentzen, 2020).

The other reason was probably curiosity as to whether and how online streaming would work. In April 2020, the follow-up of the big religious ceremonies was accompanied by an outstanding audience, and then by the end of April and the beginning of May, the number of users was stabilized. Some erosion, in proportion to the denomination, was observed. With the end of the lockdown, and the reopening of offline opportunities, the number of streaming decreased. Where it has remained, the number of viewers is declining, but digital users have not completely disappeared. During the second wave of the pandemic, although the churches were not closed, there was a digital reversal, not to the extent of the one of spring, but the larger sites were followed by thousands and the smaller ones by hundreds.

But the question also arises: what does it mean to belong to a religious community, in addition to attending ceremonies? Greater emphasis was also placed on the digital presence of other aspects of religious community life during the pandemic, where the participatory culture can be better developed than in the case of the streamed worship services. These can be education, the opportunity to give reflections, the opportunity for dialogue within the community, the experience of cooperation and support. Two of the Hungarian groups can be highlighted, one of which is the This Day! Movement and the other is the 777 online religious community. The Facebook page of the This Day! Movement has 220,000 followers, and the music content it shares is the most popular. The Facebook page of the $777 \mathrm{blog}$ is followed by 75,000 people, and when the 777 community invited its followers to a common prayer at 8:00 pm on 15 November 2020, more than 60,000 people were present on the site, and according to the digital map not only from Hungary or Europe, but there were literally logins from every continent. In the cases mentioned above, in addition to the nature of the event, the online community also has a significant role to play in the large number of views of the broadcast.

During the pandemic, churches had to take care not only to stream their religious ceremonies online, but also to create community opportunities in the digital space. What 
platform was chosen for this was a matter of consideration, as the technological options were not neutral. Thinking of neutrality in the sense that different numbers of believers would be able to connect to the conversation with a microphone and a camera, and different types of interaction would be allowed by each platform.

In addition to Facebook likes, you can also make comments and share content. Incidentally, it was in connection with mass streaming that an interactive solution could be seen in which believers wrote passages that would have been said live during the ceremony as a commentary. There were those who, using hashtags, indicated that they belonged to some religious community. In the case of Zoom or Teams, the intention to reflect can also be muted, and applause can be expressed with icons. According to American pastor Nandra Perry, the charisma of Zoom Church is that (American) rural churches have a good opportunity for growth (Perry 2020). The different platforms provide the experience of social presence various ways. However, do the group members really see each other or can only the current speaker be on the screen? What impressions does the split screen make in the host, is this impression the same or at least similar to the offline experience of the group? It is important since the method of presentation often affects the credibility of the representation. In our highly visual culture, the empty rows of benches and lonely priests seen in steamed videos did not enhance the sense of community, especially not when all other forms of interactive feedback were missing from the broadcast (Campbell 2020c). Some have come up with a solution by putting a portrait of their believers on the benches. Therefore, knowing the community, the type of group, and its internal structure is extremely important to choose the right technological platform to conduct their online gatherings, since the success of the digital switchover depends on it. If a bad solution is chosen that does not "adapt" to the structure and needs of the community, the online transition will fail. The aim in these cases is that the digital space should not only be a place where members "go on", but also provide an opportunity to experience social connections, to be able to convey a sense of personal support. A new type of technological environment must be sought or created that meets religious, spiritual needs. This digital environment cannot be chosen only from existing platforms, but also can be created new ones. As a church leader, this is exactly what Troy Shepherd did when he developed an application called SURROUND. It has created a technological tool that is consistent with the values and mission of the church to build a spiritual community with real meaningful relationships (Shepherd 2020). In the 2020 period of the pandemic, we found no example of Hungarian churches and religious communities creating their own platform similar to SURROUND. But we have noticed in case of some communities that they have provided their sites with a password or an access code. With this, they have achieved that only those who belong to the offline community have access to digital content and broadcasts, others have not.

New patterns of an individual's connection to a religious community could emerge in the digital space. And although this transformation had already begun earlier, it became more intense out of necessity during the quarantine.

\section{Discussion}

\subsection{Theological Considerations of Network Presence}

When presenting the effects related to the pandemic, it is first appropriate to outline the theological issues and reflections that the "switch" to the network surfaces in the institutional churches raised, how they think about the rituals, rites, and prayers displayed online. As well as how to think about online strategy in addition to offline, it is also becoming a basic requirement in churches. In accordance with the regulations of the Government Decree published on 11 March 2020, the Hungarian Catholic Episcopal Conference announced on 17 March 2020 that "Churches as places of spiritual recharge and prayer are especially important, therefore they are not to be closed. Yet we must act responsibly and prudently, and the public liturgy will be suspended in the churches from 4 March 2020." The Presidium of the Synod of the Hungarian Reformed Church announced on March 16 that all religious events would be suspended. The bish- 
ops of the Hungarian Lutheran Church have asked all parishes in the country not to hold worship or other services from March 16, and to hold funerals only as narrowly as possible. The United Hungarian Jewish Community closed the synagogues, and on Friday, March 20, 2020, they no longer gathered for a joint celebration. (http://refo rmatus.hu/mutat/17143/, https:/ / katolikus.hu/cikk/az-mkpk-kozlemenye-31256994, https://hvg.hu/itthon/20200315_evangelikus_istentisztelet_egyhaz_koronavirus, https: //tfilin.hu/udvarias-mincha-koronavirus-idejen-rabbi-oberlander-baruch/, accessed on 10 April 2020).

Due to the closures, the most pressing issue for churches was how to ensure that the possibility of community services was maintained. In 2020, when traditional mass communication channels had long been broadcasting religious ceremonies, it was obvious to think over the mediatization of services. In a theological sense, the work did not have to start from beginnings either, as the churches already had guidelines for using the digital sphere. In the case of the Catholic Church, for example, we can mention, the papal documents, the Church and the internet, and the ethics of the internet.

In this situation in spring, as a researcher, it was worth analyzing how each church determines the "status" of a mediated event relative to the offline event as normative. According to the historical churches, the real and the mediated situation are by no means the same, they are not equivalent and are not interchangeable. According to the provisions of the Catholic Church, the buildings were not closed and the priests continued to mass without the physical presence of the believers. Masses were broadcast online from many places, and the public service media did the same on Sundays, in connection with which the Catholic Church's statement encouraged attendance. Regarding the status of the broadcast Mass it could be read "The physical presence at the Mass is not replaced by the screen Mass." (Sajgó 2020) Since in the Catholic Church only the consecration of Sunday is obligatory (which can be prayer or spiritual deepening) it is not necessary to get involved in the broadcast of Mass. "No one is required to attend screen Mass. However, all believers are still obliged to consecrate Sunday and public holidays." (Sajgó 2020) Several suggestions are offered: the believers should be prepared for the streaming, have the appropriate attire on, stay on the screen Mass till the end, and do not eat or drink during the prayer. It is also recommended to turn off the phones. During the streaming, it is recommended to follow the decent body position and the rite-standing up, kneeling and casting a cross. Make a spiritual sacrifice during Holy Communion. And finally, take some time after the screen Mass (Sajgó 2020). The Catholic Church also offers prayers for more effective involvement in the process of the ceremony.

They thought otherwise in the Orthodox Church. John Zizioulas, a metropolitan of Pergamum, one of the dominant leaders of the Orthodox Church, disagrees and does not support the online or television broadcast of the ceremonies, as he declares the liturgy requires a personal presence. If people are locked in their homes due to the pandemic, it is worth reading sacred texts, but not the text of the sacred liturgy (https:/ / publicorthodoxy. org/, accessed on 23 March 2020). His guidelines were followed in Hungary as well.

The guidelines of the Hungarian Reformed Church were as follows: "The communion at home indicates an emergency (serious illness, lockdown, pandemic, war). It does not replace the communion feast of the church community, but in extraordinary situations it is necessary to experience the mysterious communion with Christ in the power of the Holy Spirit in the communion." The course of the ceremony in this case is engaging in worship through the medium and receiving communion at home. The pastor can decide whether or not to partake of the communion in worship, and if so, the family decides whether or not to partake of the communion in their home. That there is no consensus on the issue among pastors or believers is also indicated by the text: pastors who do not hold the communion "should have the same understanding for their colleagues who consider it possible to include the communion in streamed worship.... We also understand church members who, for various reasons, are unwilling or unable to take the opportunity of a 
communion at home." (https:/ / reformatus.hu/egyhazunk/hirek/istentiszteleti-ajanlasokkrizishelyzetben/, accessed on 1 April 2020).

The Jews prepared to commemorate Seder night during the pandemic. To celebrate according to their traditions, the Chabad Lubavitch Movement gave the following advice: In the Talmud, the question arises: what should one do sitting alone at the Seder table? To whom should you ask the "Má nistánát?", the four questions, and who will answer them? As our sages say in such a case one should ask oneself and give the answers too. An electrical device cannot be turned on by Jews on Saturday, and the phone and the computer are no exception: "Of course, everyone agrees that it is forbidden to use this and other electrical technology on holidays or on Sabbaths. Based on this, it is not acceptable to start and broadcast a Sabbath reception and evening prayer live on Facebook, it is the breaking of Sabbath for both those who broadcast it and those who watch it. On the day of Purim, many turned to the Budapest Orthodox Rabbinate with the question of whether they could listen to Megila, the book of Esther, live on the Internet. The following is a summary of the advice of Rabbi Oberlander Báruch: "The question arises why it is forbidden to do the Mitzvah by telephone or Facebook streaming. The answer to this was given by the Lubavitch Rebbe, in 1964. As he writes (Sulchán Menáchem, Volume 3, pp. 319-20), one who is familiar with technology knows that when a person hears another person's voice through a microphone or telephone, they are actually hear a sound that is "imitated" by the machine and not real voice. The device converts the sound into signals, which are then recomposed into sound in the other device. From this point of view, it makes no difference whether we listen to a recording of a chief cantor 100 years ago or a live streaming on Facebook: in either case, we hear the sound of the machine, not the man. Based on the above instruction of the Sulchán áruch, I think it is even better to read the text as a reminder to oneself without a blessing. ... Rebbe added that there are reputable rabbis who think it can be carried out over the phone, but unfortunately their text reveals that those who explained them how the technology works were seriously mistaken". That is, it is not a question of halachic debate, but an understanding of a technique, so Rebbe's opinion on this issue was accepted by the vast majority of the rabbinical word." In December, Hanukkah was already celebrated online by the Jews community.

\subsection{The Challenges of Digital Technology}

The online streaming of church and religious ceremonies and the networking of community church events raised a number of issues for participants. One of these is the convergence of roles, knowledge and skills in the process. As the priest, pastor, or rabbi who streamed a ceremony had to hold not only a religious role but also a technical one. In the context of a digital recollection the remembrances of a Jesuit monk also reveal humorous moments "Fragility can sometimes be ridiculous, no matter how much we try. So were others. "Hold on, my altar has collapsed!" Or, "Can you see me this way? Then I will get dressed as a priest and we can start. " When I uttered such sentences, I was simultaneously touched and had to laugh a lot," wrote the monk. He also reports that despite the physical and technical difficulties the recollection worked. He mentions that the border between the layman and the clergy may blur: "In the new circumstances caused by the coronavirus, when your family home becomes the temple of our church and you are the priest of your family, you are especially needed!" (Nagy 2020).

He writes about the problem and solution of creating a visual presence, an appearance on the screen, "When we weren't in our place, we still left some small object, an icon in front of our monitor, to show we were present to each other." (Nagy 2020). At this point it is worth staying longer, as the way the visual composition can create an extra meaning in relation to the event, influences the meaning-making in the recipient. What should be considered when imaging? The first is perhaps the point of view of where the viewer's gaze is positioned during the broadcast. The angle of the recording (whether the event is visible from below or from above) can affect the recipient's feelings. In the specific situation, this meant how closely the altar, the pastor in real life could be seen, perhaps so closely 
that it was not common. Whether the leaders of the ceremony are looking at the camera to make eye contact with the viewers or they are looking towards the empty rows of benches, or they are looking inwards. But light and shadow conditions can also affect viewers, it will be meaningful where the light falls and what is shadowed. With image depth and contrast, tension can be created, while the viewer's attention can be directed by alternating plans (Antal et al. 2015, pp. 66-68, 124-28). Although the broadcasts were mostly made with a single fixed camera, there were also technical assistants available for the church and then the stream was recorded with several cameras and presented by the director. But whichever solution was chosen it was definitely a new visual reality for the recipients. The technically mediated ceremonies offer a new way of experiencing the ritual, as for example no one has seen the ceremony from above before. The ceremony around which the liturgical context is built, which presents a dramatized event. In addition, the viewer can follow the process from within and engage either as an observer or participant. At the same time, both the clergy and the laymen said that the authenticity of the online ceremonies was not meant by flawless technological solutions, professional picture and sound quality. There was also an American pastor, Steve Evoy, whose congregation consisted of elderly people from the countryside. His community experienced credibility not in the perfect technology transfer of the offline mass, but rather in immersing himself in a "spiritually" familiar activity. The pastor therefore regularly shared "fireside chats", in fact monologues, and this solution was a success in his community (Evoy 2020). Another church leader, Zach W. Lambert, also considers connectivity more important than shared content or its quality (Lambert 2020).

\subsection{Changed Recipient Context}

The need and cooperation of believers who in the pre-pandemic period regularly went to church was also required for the online transmission of church ordinances. The chapter also covers skills and the spatial and temporal context of inclusion.

Church documents produced at the time of the lockdown show that online ceremonies focused primarily on helping with spiritual preparation, less on technology, although some can be mentioned of this type too. This is presumably due to the fact that the technical skills of the community were considered appropriate for the digital switchover. In the Reformed Church's recommendation for spiritual preparation, we read: "We ask our brethren to prepare both physically and spiritually for the mediated worship as they did when they set out for the house of God in a non-emergency time. Please create the conditions for full attention and engagement, prepare Scripture and the hymnbook for the duration of the broadcast, turn off devices that interfere with or hinder full attention, and set aside all other work and activities. We ask that they engage in mediated worship in the same way as is usually the case: together we say the prayers, we sing the songs."

It is also important how the faithful, the religious families, relate to the mediated ceremonies and events, how they interpret them. For example, how do they define their own role in the ceremony: as an observer or participant, whether or not they follow the regulated part of the liturgy in actions, sing, or respond according to the rite? Although specific decisions in this regard are made in the discourses of families, the effects of network technology can be explored at three points. These effects are related to space (network, mediated, and sacral space) as well as networked time and timelessness.

One of the peculiarities of mass communication is that the public sphere and topics are presented in the private spaces. This effect was particularly strong in the case of television, which made public spaces visually receptive to the living rooms of homes. The current situation, the online transmission of religious ceremonies, is different in that it takes over not only public but also sacred spaces in the private space. And in the sacred space, people behave differently than in their living room. Some of the family discourses were about: how to get dressed for streaming, whether the slippers can stay, whether you can stand up and leave in the meantime; to eat or drink.

The answer, of course, is rarely black or white, but rather we see a kind of transition between private and sacred space. When secularization pushed religion out of the public 
sphere, it pushed it into the private spaces. Religion, the practice of faith, had been present in the spaces of private life. That is, the sacred space also appeared in the private space of the home. In the case of Jews, the placement of the mezuzah still suggests this. Referring to Belden C. Lane, American religion researcher Kim Knott writes that sacred spaces are not pre-existing, but average, ordinary spaces that, in connection with a rite, become sacred in the process of ritualization. Within these, Knott is interested in how the distinction between public and private spaces works in believers' homes and how it supports the personal (primarily female) spiritual development (Knott 2005, p. 95). In creating the sacred space within the home, several religious leaders mentioned the possibility of creating a home altar, the centuries-old traditions of which were revealed by ethnography when it tells about the so-called sacred corner as a place of private devotion (Sajgó 2020; Csukovits 2016). The Benedictine community recommended setting up a prayer corner: "Prepare a prayer corner (with candle, cross, Scripture)!" Through the Creative Easter program, it guided the believers with musical and film experiences related to the spiritual program during the Holy week. The Jesuits gathered the digital opportunities offered by the order "during Internet pastoral care at home". In a spiritual report, we read, "Maybe I didn't even think at first that it could work that way. Our own room has become a church. Our bedside table is an altar, our candle bought in the drugstore is an everlasting candle." (Nagy 2020).

In addition, new offline liturgical forms were created when masses or processions were performed on the street or in other public spaces. This new form was called "Eucharist to-go".

The digital presence and network communication have changed not only space, but also time and time access, since while churches broadcast religious events live on the internet, recipients and participating believers are far from certain that they will watch them live and not from a recording. Again, it is family autonomy to decide whether or not to follow events in real time. I believe that the more time churches spend in the digital space, the stronger the effects of the network will be.

In fact, both in terms of space and time, we can say that network communication duplicates context, not only the physical context of perception is important, but also the digital environment. That is, what other contents pop up during the streaming.

Ultimately, Anita Cloete mentions curiosity, competition, and popularity based on the criteria by which believers look for a mass that is right for them (Cloete 2020). However, I believe that at least four factors are worth considering when evaluating decision-making: spiritual, thematic, aesthetic, and medial considerations. By spiritual, it means the authenticity of the ceremony, the sense of authenticity, and by thematic, how relevant, interesting or entertaining content the recipient is looking for. For the aesthetic aspects, it means good image quality, clear sound, professional editing, while for the media aspect, it means the speaker's reputation, fame, and competition with the like. A religious person will choose from the options according to his or her own preferences.

In connection with the recipients three more issues can be mentioned briefly. One is the more striking generational differences in the digital environment. By this meant that young people, digital natives, became familiar with online broadcasts much sooner. And they probably belonged to an online or hybrid (offline and online at the same time) religious community even before the lock down. They also think differently about authenticity and authority in the digital space than their older counterparts.

Secondly data security issues can be mentioned. In some cases, the community did not trust the service provider with regard to the platforms used for online meetings. This fear could be encountered primarily in German descriptions, mentioned by Ralf Peter Reimann, and in the case of Hungarians, by members of the 777 community (Reimann 2020; Andok and Vígh 2017).

In one case, copyright notices for online-broadcast funerals were also found. An article helped the mourners with organizing the broadcast of the ceremony. And one point is to pay attention to copyright, since if the mourning music is protected by copyright the Facebook will mute the broadcast. 
The pandemic was also reflected in politics, the relationship between religion and politics. U.S. President Donald Trump declared 15 March 2020, a national day of prayer in the United States, when believers in various churches could pray for the victims of the coronavirus. The proclamation mentions that due to the pandemic, people cannot go to churches, mosques, synagogues, but prayer is much needed. tTe president cites several biblical passages: 1 Peter 5: 7, Psalm 91, and Luke 1:37. (Available: https:/ /trumpwhitehouse.archives .gov/presidential-actions/proclamation-national-day-prayer-americans-affected-coronav irus-pandemic-national-response-efforts/, accessed on 14 March 2020) In Hungary, Foreign Minister Péter Szijjártó indicated in his post on November 15 that he had joined the call of 777 community, and at eight o'clock in the evening he prayed with the community for the victims of the pandemic.

\section{Conclusions}

The study reviewed how the online appearance of Hungarian churches and religious communities changed during the coronavirus pandemic, and how the digital transition (or rather extension) accelerated, accompanied by a theological clarification work on the part of the churches. Formerly offline churches, it has even become possible (and, in a sense, a compulsion) to appear online. These mostly involved the online broadcasting of offline ceremonies, in which many smaller parishes were also involved. In addition to streaming ceremonies, religious communities and groups also expanded their practices to online interfaces. Digital prayer rooms, supporter talks, and virtual cafes have also appeared.

It became clear that there was no universal, equal solution for the online appearance of religions and churches; there were those who easily adapted their activities to the digital interface and there were those who did not, or even rejected it. Flexible, innovation-open communities could adopt to online participation more easily. Quarantine has revealed technological opportunities that were previously unnoticed by religious communities. In the first wave of the pandemic, the big holidays of spring were online for all world religions (e.g., Easter, Seder, Ramadan). The same happened during the second wave of winter in the celebration of Christmas and Hanukkah.

Experiences show that two waves of digital switchover can be identified in Hungary for religions. At the beginning of the pandemic in Hungary, in the first wave of the digital transition, the same religious ceremony and rite were transmitted from the offline stage to the digital online interface. The transition was not really medium (Internet, network communication) specific; the goal was simply to record and broadcast real acts to the believers and the channel could have been anything (even classic television). During this period, the attention of content creators and distributors focused on technology and its uses. The goal was to create and emphasize the visual similarity of experience as much as possible. The problems occurred in this area, technology transmission, and the availability and accessibility of equipment. In the second wave, attention was paid to the recognition of network media effects and the moderation of these. And the newly discovered opportunities came to the fore. Observations about the Hungarian situation were confirmed by the international literature, although they distinguish three strategies: the first is transmission, the second was translation, and the third was transformation (Campbell 2020a). Here, we believe that the phase of transformation is still to come in Hungary.

Funding: This research received no external funding.

Institutional Review Board Statement: Not applicable.

Informed Consent Statement: Not applicable.

Conflicts of Interest: The author declares no conflict of interest. 


\section{Notes}

1 Streamed contents available https://www.youtube.com/watch?v=0yv5T4a2FlQ, https: / / www.youtube.com/watch? v=UZ KeJymVygk, https: / / www.youtube.com/watch?v=Luqoeh-zbzo, https:/ /www.youtube.com/watch?v=EgY7w3ZIDCU, ht tps:/ / www.youtube.com/watch?v=UZKeJymVygk, https:/ / www.youtube.com/channel/UC4kcszDESGY4kN6M6hV3afA, https:/ /zsido.com/virtualis-bet-midras/ (acessed on 20 April 2020).

\section{References}

\section{Archive Sources}

777 közösség (777 community). Available online: https:/ / www.facebook.com/777blog.hu (acessed on 16 March 2020).

A Magyarországi Református Egyház Zsinatának Elnöksége: 2020. March 16. Szüneteltessenek minden egyházi alkalmat. (Presidency of the Synod of the Hungarian Reformed Church: March 16, 2020 Pause all church opportunities). Available online: http: / / reformatus.hu/mutat/17143/ (acessed on 16 March 2020).

A Szolnoki Református Egyházközség online istentisztelete 2020. március 29. Böjt 5. vasárnapja. (Online worship of the Szolnok Reformed Parish). Available online: https://www.facebook.com/groups/845140862575770/posts/850526355370554 (acessed on 29 March 2020).

Adkins, Todd: 2020. April 23. 4 Tips for Livestreaming a Funeral Service. Available online: https://factsandtrends.net/2020/04/23/4-tips -for-livestreaming-a-funeral-service/ (acessed on 23 April 2020).

Az evangélikus egyház betiltotta az istentiszteleteket Magyarországon. 2020. March 15. (The Lutheran Church banned worship in Hungary.) Available online: https://hvg.hu/itthon/20200315_evangelikus_istentisztelet_egyhaz_koronavirus (accessed on 15 March 2020).

Daily Readings and Homily. 13 April 2020. Available online: https:/ /www.youtube.com/watch?v=QeOMZ5O79fg\&list=PL98FC02E5A A17A7C8\&index=478 (accessed on 13 April 2020).

Ferences Rendtartomány. (Franciscan Province) Available online: https://www.youtube.com/channel/UC4kcszDESGY4kN6M6hV3a fA (acessed on 21 April 2020).

Foley, John P. 2002. Pontifical Council for Social Communications. Ethics in Internet. Available online: https://www.vatican.va/roman_cur ia/pontifical_councils/pccs/documents/rc_pc_pccs_doc_20020228_ethics-internet_en.html (acessed on 23 April 2020).

Három óra alatt 7000 ember csatlakozott az imalánchoz. (In three hours, 7000 people joined the prayer chain). Available online: https: / / www.facebook.com/777blog.hu/posts/1530744267083267 (acessed on 18 March 2020).

Húsvét vigíliája, Szent István Bazilika. 2020. ápr. 2. (Easter Vigil, St. Stephen's Basilica). Available online: https:/ / www.youtube.com/ watch?v=0yv5T4a2FlQ (acessed on 2 April 2020).

Húsvéti vigília a pannonhalmi bazilikában. Élő közvetítés dátuma: 2020. ápr. 11. (Easter vigil in the Pannonhalma Basilica. Date of Live Broadcast: Apr 2020 11). Available online: https: / www.youtube.com/watch?v=Luqoeh-zbzo (acessed on 11 April 2020).

Istentiszteleti ajánlások a krízishelyzetben. 2020. April 1. (Worship recommendations in a crisis situation.) Available online: https:/ / reformatus.hu/egyhazunk/hirek/istentiszteleti-ajanlasok-krizishelyzetben/ (acessed on 1 April 2020).

Karikagyứrú választási tippek. (Wedding Ring Selection Tips). Available online: http:/ / www.segitoszuzmaria.hu (acessed on 1 April 2020).

Katolikus Szentmise, Dunaszekcső (Catholic Holy Mass, Dunaszekcső). Available online: https:/ /www.facebook.com/watch/?v=3498 04032677408 (acessed on 20 April 2020).

Keresztény közvetitések gyüjteménye. (Christian Broadcasts Collections). Available online: https://www.facebook.com/groups/84514086 2575770 (acessed on 28 April 2020).

Magyar Katolikus Püspöki Konferencia 2020. March 17. Az MKPK közleménye. (Hungarian Catholic Episcopal Conference March 17, 2020 Announcement of the MKPK). Available online: https:/ / katolikus.hu/cikk/az-mkpk-kozlemenye-31256994 (acessed on 17 March 2020).

Magyarországi Vallási Közösségek Adatbázisa-MAVALLKA (Database of Religious Communities in Hungary). Available online: https: / / www.mavallka.hu (acessed on 27 March 2020).

Metodista Istentisztelet. 2020. máj. 17. (Methodist Worship). Available online: https://www.youtube.com/watch?v=ejvrUwTZiMI (acessed on 17 May 2020).

Middletone, Joe 2020 More than HALF of Young People Are Praying Online during Pandemic. Available online: https:/ / www.dailymail.co .uk/news/article-8619383/More-HALF-young-people-praying-online-pandemic.html?fbclid=IwAR1JmeN-hPZTGNO2SySZ E-i-Hxm YnPULW85Brmhn4I-HPvXiKwBrY7YA1J4 (acessed on 15 May 2020).

Nagypénteki szertartás a Szent István-bazilika Mária-kápolnájából. 2020. ápr. 10. (Good Friday ceremony from the Chapel of Mary in St. Stephen's Basilica. Apr. 2020 10). Available online: https:/ /www.youtube.com/watch?v=RCpbu0K6uU0\&list=PLC7BrO_Z PZAA8knE5zrKIFlfAV8Of0A8_\&index=705 (acessed on 10 April 2020).

Nagytemplomi húsvét vasárnapi Istentisztelet—2020. április 12. 10 óra, (Great Church Easter Sunday Worship-April 12, 2020 at 10 a.m.). Available online: https://www.youtube.com/watch?v=EgY7w3ZIDCU (acessed on 12 April 2020).

Népszámlálás 2011. (Census 2011). Available online: http:/ /www.ksh.hu/nepszamlalas/tablak_vallas (acessed on 24 April 2020).

Oberlander Báruch 2020-03-17-22 ADAR 5780. Udvari(as) mincha koronavírus idején. (Polite mincha at the time of coronavirus). Available online: https:/ /tfilin.hu/udvarias-mincha-koronavirus-idejen-rabbi-oberlander-baruch/ (acessed on 17 March 2020). 
Oberlander Baruch: Álhír a videokonferencia Széder. (Fake news about video conferencing in Seder). Available online: https: / / zsido.com/alhir-a-videokonferencia-szeder/ (acessed on 21 April 2020).

Pannonhalmi Főapátság: Virágvasárnap 2020. March (Archabbey of Pannonhalma: Palm Sunday). Available online: https:/ / pannon halmifoapatsag.hu/kreativ-viragvasarnap/ (acessed on 14 March 2020).

Pünkösdszombat ünnepi szentmise. Élő közvetítés 10—órától. Május 30. 2020 (Pentecost festive Mass. Live broadcast from 10 a.m.). Available online: https:/ / www.youtube.com/watch?v=UZKeJymVygk (acessed on 30 May 2020).

Szijjártó Péter 2020. november 15. Karanténnapló -13. nap, 2. rész (Quarantine Log). Available online: https: / / www.facebook.com/szi jjarto.peter.official/photos/214505703375321 (acessed on 15 November 2020).

Trump, Donald J. 2020 March 14. Proclamation on the National Day of Prayer for all Americans Affected by the Coronavirus Pandemic and for our National Response Efforts. Available online: https://trumpwhitehouse.archives.gov/presidential-actions/proclama tion-national-day-prayer-americans-affected-coronavirus-pandemic-national-response-efforts / (acessed on 14 March 2020).

Ünnepeink. (Our holidays) Available online: https:/ /zsido.com/unnepek/aktualis-unnep/ (acessed on 24 April 2020).

Virágvasárnap konventmise a pannonhalmi bazilikában. Élő közvetítés dátuma: 2020. ápr. 5. (Palm Sunday convent in the Pannonhalma Basilica. Date of live broadcast: Apr 2020 5). Available online: https:/ /www.youtube.com/watch?v=687vFJx2gt8\& list=PLHI88zWI08AI2xIXaI1LrAfkQsrhftpjC (acessed on 5 April 2020).

Virtuális Bet Midras (Virtual Bet Midras). Available online: https:/ /zsido.com/virtualis-bet-midras/ (acessed on 24 April 2020).

Zizioulas, John Metropolitan Of Pergamon March 23, 2020. The Church Without The Eucharist Is No Longer The Church. Available online: https:/ / publicorthodoxy.org/ (acessed on 23 March 2020).

\section{Published References}

Ammerman, Nancy T. 2003. Religious identities and religious institutions. In Handbook of the Sociology of Religion. Edited by Michele Dillon. Cambridge: Cambridge University Press, pp. 207-24.

Andok, Mónika. 2017. Hálózati kommunikáció és egyház. In Intézmény és Karizma az Egyházban 2.0: Ünnepi kötet Tomka Ferenc Tiszteletére 75. Születésnapja Alkalmából. Edited by Máté-Tóth András. Budapest: Szent István Társulat, pp. 102-24.

Andok, Mónika. 2018. Media, Religion and Public Sphere: International Trends and Hungarian Researches. KOME—An International Journal of Pure Communication Inquiry 6: 16-31. [CrossRef]

Andok, Mónika, and Fanni Vígh. 2017. Religious communities' digital media use: A Hungarian case study. In Believe in Technology: Mediatization of the Future and the Future of Mediatization. Edited by Michaela Alexandra Tudor and Stefan Bratosin. Les Arcs: IARSIC, pp. 378-92.

Antal, Zsolt, Gazsó Tibor, and Kubínyi Tamás. 2015. Pelle Veronika: Médiabefolyásolás—Az új Kislexikon. Budapest: Századvég Kiadó.

Barabási, Albert-László. 2013. Behálózva. A Hálózatok új Tudománya. Budapest: Helikon Kiadó.

Berger, Teresa. 2020. @ Worship Goes Viral: Catholic Liturgy Online in a COVID-19 World. In Digital Ecclesiology: A Global Conversation. Digital Religion Publications, Network for New Media, Religion \& Digital Culture Studies. Edited by Heidi A. Campbell. Texas: Texas A \& M University, pp. 14-20.

Bogle, Albert. 2020. Turning Flavor of the Month into Staple Diet. In The Distanced Church: Reflections on Doing Church Online. Digital Religion Publications. An Imprint of the Network for New Media, Religion E Digital Culture Studies. Edited by Heidi A. Campbell. Texas: Texas A \& M University, pp. 7-10.

Boyd, Danah. 2014. It's Complicated. The Social Lives of Networked Teens. New Haven: Yale University Press.

Campbell, Heidi A. 2006. Religion and the Internet. Communication Research Trends. A Quarterly Review of Communication Research 25: 3-18.

Campbell, Heidi A. 2010. When Religion Meets New Media. London: Routledge, New York: Taylor and Francis Group.

Campbell, Heidi A. 2013. Digital Religion. Understanding Religious Practice in New Media Worlds. London: Routledge, New York: Taylor and Francis Group.

Campbell, Heidi A., ed. 2020a. The Distanced Church: Reflections on Doing Church Online. Digital Religion Publications. An Imprint of the Network for New Media, Religion \& Digital Culture Studies. Texas: Texas A \& M University.

Campbell, Heidi A., ed. 2020b. Religion in Quarantine: The Future of Religion in a Post-Pandemic World. In Digital Religion Publications An Imprint of the Network for New Media, Religion E Digital Culture Studies. Digital Religion Publications, An Imprint of the Network for New Media, Religion \& Digital Culture Series; Texas: Texas A \& M University.

Campbell, Heidi A., ed. 2020c. Digital Ecclesiology: A Global Conversation. In Digital Religion Publications, Network for New Media, Religion \& Digital Culture Studies. Digital Religion Publications, An Imprint of the Network for New Media, Religion \& Digital Culture Series; Texas: Texas A \& M University.

Campbell, Heidi A., and Alessandra Vitullo. 2016. Assessing changes in the study of religious communities in the digital religion studies. Church, Communication and Culture 1: 73-89. [CrossRef]

Carey, James W. 2009. Communication as Culture. Essays on Media and Society, revised ed. New York and London: Routledge.

Cheong, Pauline Hope, Peter Fischer-Nielsen, Stefan Gelfgren, and Charles Ess, eds. 2012. Digital Religion, Social Media and Culture. Perspectives, Practices and Future. New York: Peter Lang Publishing.

Chetty, Denzil. 2017. The Formation of Online Religious Identities: A Case Study of the Internet-Hindi in India's Cyberspace. In Digital Hinduism. Dharma and Disclosure in the Age of New Media. Edited by Balaji. Lanham: Lexington Books, pp. 25-46. 
Cloete, Anita. 2020. The Church is Moving On(line). In Digital Ecclesiology: A Global Conversation. Digital Religion Publications, Network for New Media, Religion E Digital Culture Studies. Edited by Heidi A. Campbell. Texas: Texas A \& M University, pp. 27-32.

Connelly, Louise. 2013. Virtual Buddhism. Buddhist ritual in Second Life. In Digital Religion. Understanding Religious Practice in New Media Worlds. Edited by Heidi A. Campbell. London: Routledge, New York: Taylor and Francis Group, pp. 128-35.

Csukovits, Anita. 2016. A népi vallásosság emléktárgyainak megőrzése, jelentősége A dunakeszi Szent Mihály-templomban rendezett kiállítás megnyitóbeszéde. Dunakeszi Helytörténeti Szemle 9: 14-17.

Danielsson, Arni Svanur. 2020. Connection Trumps Technology. In The Distanced Church: Reflections on Doing Church Online. Digital Religion Publications. An Imprint of the Network for New Media, Religion E Digital Culture Studies. Edited by Heidi A. Campbell. Texas: Texas A \& M University, pp. 10-12.

Elmasry, Mohamed Hamas, Auter Philip J., and Peuchaud Sheila Rose. 2014. Facebook across Cultures: A Cross-Cultural Content Analysis of Egyptian, Qatari, and American Student Facebook Pages. Journal of Middle East Media 10: 27-60. [CrossRef]

Evoy, Steve. 2020. The Unspectacular Pastor: Live and In Person. In The Distanced Church: Reflections on Doing Church Online. Digital Religion Publications. An Imprint of the Network for New Media, Religion E Digital Culture Studies. Edited by Heidi A. Campbell. Texas: Texas A \& M University, pp. 15-17.

Fewkes, H. Jacqueline. 2019. Piety in the Pocket: An Introduction. In Antropological Perspectives on the Religious Uses of Mobile Apps. Edited by H. Jacqueline Fewkes. Cham: Palgrave MacMillan, pp. 1-17.

Floberg, John. 2020. The Challenges of Online in Indian Country \& Rural America. In The Distanced Church: Reflections on Doing Church Online. Digital Religion Publications. An Imprint of the Network for New Media, Religion E Digital Culture Studies. Edited by Heidi A. Campbell. Texas: Texas A \& M University, pp. 17-19.

Golan, Oren, and Michele Martini. 2019. Religious live-streaming: Constructing the authentic in real time. Information, Communication and Society 22: 437-54. [CrossRef]

Helland, Christopher. 2000. Online-religion/Religion-online and Virtual Communitas. In Religion on the Internet: Research Prospects and Promises. Edited by Jeffrey K. Hadden and Douglas E. Cowan. New York: JAI Press, pp. 205-33.

Helland, Christopher. 2013. Ritual. In Digital Religion. Understanding Religious Practice in Nem Media Worlds. Edited by Heidi A. Campbell. London: Routledge, New York: Taylor and Francis Group, pp. 25-40.

Hepp, Andreas, and Veronica Krönert. 2010. Religious Media Events. The Catholic "world Youth Day" as an example of the mediatization and individualization of religion. In Media Events in a Global Age. Edited by Nick Couldry, Andreas Hepp and Friedrich Krotz. London: Routledge, New York: Taylor and Francis Group, pp. 265-82.

Hjalvard, Stig. 2016. Mediatization and the changing authority of religion. Media, Culture E Society 38: 8-17.

Hoover, Stewart M. 2006. Religion in the Media Age. Oxon: Routledge, New York: Francis \& Taylor, p. 352.

Hoover, Stewart M. 2012. Foreword: Practice, Autonomy and Authority int he Digitally Religions and Digitally Spiritual. In Digital Religion, Social Media and Culture. Perspectives, Practices and Future. Edited by Pauline Hope Cheong, Peter Fischer-Nielsen, Stefan Gelfgren and Charles Ess. New York: Peter Lang Publishing, pp. vii-xii.

Jenkins, Henry. 2006. Convergence Culture: Where Old and New Media Collide. New York: New York University Press.

Knott, Kim. 2005. The Location of Religion. The Spatial Analysis. London and Oakville: Equinox Publishing.

Korpics, Márta. 2014. A szakrális kommunikáció szinterei: A zarándoklat. Budapest: Typotex Kiadó.

Lambert, Zach W. 2020. Facilitating Deep Friendship Digitally When Analog Acquaintances are Gone. In The Distanced Church: Reflections on Doing Church Online. Digital Religion Publications. An Imprint of the Network for New Media, Religion $\mathcal{E}$ Digital Culture Studies. Edited by Heidi A. Campbell. Texas: Texas A \& M University, pp. 19-22.

Lövheim, Mia. 2012. Identity. In Digital Religion. Understanding Religious Practice in New Media Worlds. Edited by Heidi A. Campbell. London: Routledge, New York: Taylor and Francis Group, pp. 27-38.

MacDonald, Andrew, Ed Stetzer, and Todd Wilson. 2020. COVID-19 Church Survey Summary Report. How Church Leader are responding to the Challenges of COVID-19. The Billy Graham Center's Send Institute, Exponential, Leadership Network, Catalyst, Discipleship.org, and ARC. Available online: https:/ / exponential.org/resource-ebooks/response-to-covid-19/tps: / / exponential.org (accessed on 17 November 2020).

Mann, Joshua L. 2017. Mobile Liturgy—Reflections on the Church of England's Daily Prayer App. Heidelberg Journal of Religion on the Internet 12: 42-59.

Miczek, Nadia. 2008. Online Rituals in Virtual Worlds Christian Online Services between Dynamics and Stability. Online-Heidelberg Journal of Religions on the Internet 3.1: 144-73.

Nagy, Bálint. 2020. Valóságos isten egy digitális világban-Megejtő beszámoló egy online lelkigyakorlatról. Available online: https:/ /jezsuita.hu/valosagos-isten-egy-digitalis-vilagban-megejto-beszamolo-egy-online-lelkigyakorlatrol/?fbclid=IwAR3k tW7zgrvRbrweBw6cbfGJEyYK7GxfadftoS3DL1Hysph_2IMrIH4DM98 (accessed on 23 April 2020).

Neriya, Rivka, and Ben Shahar. 2017. The Medium is the Danger: Discourse about Television among Amish and Ultra-Orthodox (Haredi) women. Journal of Media and Religion 16: 27-38. [CrossRef]

Perry, Narda. 2020. The Charism of Zoom Church. In The Distanced Church: Reflections on Doing Church Online. Digital Religion Publications. An Imprint of the Network for New Media, Religion \& Digital Culture Studies. Edited by Heidi A. Campbell. Texas: Texas A \& M University, pp. 29-31. 
Przywara, Barbara, Andrzej Adamski, Andrzej Kicinski, Marcin Szewczyk, and Anna Jupowicz-Ginalska. 2021. Online Live-Stream Broadcasting of the Holy Mass during the COVID-19 Pandemic in Poland as an Example of the Mediatisation of Religion: Empirical Studies in the Field of Mass Media Studies and Pastoral Theology. Religions 12: 261. [CrossRef]

Radde-Antweiler, Kerstin. 2006. Rituals-Online: Transferring and Designing Rituals. Online-Heidelberg Journal of Religions on the Internet 2: 54-72.

Reimann, Ralf Peter. 2020. Digital is the New Normal-Churches in Germany during the Corona Pandemic. In The Distanced Church: Reflections on Doing Church Online. Digital Religion Publications. An Imprint of the Network for New Media, Religion $\mathcal{E}$ Digital Culture Studies. Edited by Heidi A. Campbell. Texas: Texas A \& M University, pp. 31-34.

Rončáková, Terézia. 2021. Closed Churches during the Pandemic: Liberal versus Conservative and Christian versus Atheist Argumentation in Media. Journalism and Media 2: 225-43. [CrossRef]

Sajgó, Szabolcs. 2020. Szempontok a képernyőszentmisék kultúrájának kialakításához. (Aspects for Developing a Culture of “Screen Masses"). Available online: https://www.magyarkurir.hu/hirek/online-kegyelem-szempontok-kepernyoszentmisek-kultura janak-kialakitasahoz (accessed on 24 April 2020).

Sbardelotto, Moises. 2016. And the word became network: An analysis of the circulation of the 'Catholic' in online communicational networks. Online-Heidelberg Journal of Religions on the Internet 11: 229-53.

Shepherd, Troy. 2020. Is Your Church Ready for Social Distancing? In The Distanced Church: Reflections on Doing Church Online. Digital Religion Publications. An Imprint of the Network for New Media, Religion E Digital Culture Studies. Edited by Heidi A. Campbell Texas: Texas A \& M University, pp. 40-43.

Silverkors, David. 2020. Four Lessons I've Learned in the Wake of the Pandemic. In The Distanced Church: Reflections on Doing Church Online. Digital Religion Publications. An Imprint of the Network for New Media, Religion E Digital Culture Studies. Edited by Heidi A. Campbell. Texas: Texas A \& M University, pp. 37-40.

Sinding Bentzen, Jeanet. 2020. In Crisis, We Pray: Religiosity and the COVID-19 Pandemic. Copenhagen: University of Copenhagen CEPR, CAGE.

Tudor, Mihaela Alexandra, Benea Anamaria Filimon, and Bratosin Stefan. 2021. COVID-19 Pandemic Lockdown and Religious Mediatization of Social Sustainability. A Case Study of Romania 2021 International Journal of Environmental Research and Public Health 18: 2287. [PubMed] 